\title{
Oral Literary Tradition: Manual for K-12 Revised Curricula on Literature, History, and Social Studies
}

\author{
Doris Ogdoc-Gascon
}

\begin{abstract}
Literature has become an important tool to reflect the psyché of a group of people. This study aims to preserve these literary legacies of the Filipinos by documenting the legends and folklores of the country in English and Cebuano-Visayan (using the standardized linguistic decoding using the phoneme-grapheme correspondence) through printed texts. Moreover, recent changes with the Philippine Educational System as an effort to be at par with the rest of the world have been made through the creation of the K-12 Enhanced Basic Education Act of 2013. There is a high need for a manual that meets the requirements of the courses of the revised curricula of both the Senior High School and the higher education. Therefore, the findings of this study proposes a manual-output as a reference in teaching courses in literature, history, and social studies that are relevant and novel in today's generation of Filipinos.
\end{abstract}

Index Terms - Literary tradition, folklore, legends, Filipino collective psyche.

\section{INTRODUCTION}

The Philippines has so many oral literary traditions, yet only a limited record of them are printed and used in educational instructions. These folklores, myths, and legends are orally told from one person to another and from one generation to the next. The process of sharing the literary tradition through word of mouth poses a risk of loss of the trace of these legends. This research intends to preserve the oral literary traditions of the Philippines by making printed documents of these oral literatures through the standard Cebuano Visayan textualization and English translation.

As a result, it preserves the oral tradition of literature and becomes a means of preserving "life" that is handed down by their ancestors. This oral lore of the pre-colonial Filipinos bore the marks of the community. Basically, these oral literatures of the early Filipinos reflect the common experience of a group of people such as farming, fishing, and hunting as well as their beliefs, practices, attitudes, emotions, ideals, or wisdom [1]. Through the centuries, native literatures came to be developed as a result of the collective desire to express the thoughts, feelings, and ideals on certain matters that touched the community's interests. Before, oral literary tradition had been used to groom the conduct and mold the moral fiber of the children of the Filipinos. These oral traditions served as "artistic capsules" in which their ancestors preserved their social beliefs and values and handed down to their succeeding generations [2]. Therefore, oral

Manuscript received October 1, 2014; revised April 2, 2015

Doris Ogdoc-Gascon is with the Cebu Technological University, Philippines (e-mail: doris_ogdoc@yahoo.com). traditions apparently shape the culture of a certain people.

Furthermore, the anthologizing of the different oral literary traditions is a legacy to the next generations of Filipinos. They will be able to have a good look on the richness of the Philippine culture by appreciating the literature of a certain region in a convenient way — through reading the stories on paper. Insights will be developed as a result of the studying of these oral literary traditions. Consequently, improvement of Filipino culture is at hand when there is knowledge of the existing oral literary traditions. Filipinos will understand themselves more by studying the themes and meanings of the oral literary traditions.

Since 2013, the Department of Education (DepEd) of the Philippines has implemented the K-12 Enhanced Basic Education Act which adds two years in high school. The two-year senior high school education includes the introduction of new set of subjects, such as: (Core Curriculum) 21st Century Philippine Literature from the Regions, Personal Development/ Understanding Society \& Culture and (Specialized Track: Humanities and Social Sciences Strand (HUMSS)) Trends, Networks, and Critical Thinking in the $21^{\text {st }}$ Century Culture; Disciplines and Ideas in the Social Sciences; and Disciplines and Ideas in the Applied Social Sciences. Consequently, the Philippines' Commission on Higher Education (CHED) has to create the revised General Education Curriculum in college which consists of fewer units and is composed of a new subject which is Readings in Philippine History as well as Religions, Religious Experiences and Spirituality for the general education elective.

Cultural studies and the understanding of being a Filipino are the emphasis of the present educational system overhaul, as stated in CHED memorandum order no. 20, " knowing the self, Filipino society, the world, and the environment and how these intersect are the goals of general education". Studying the oral literary tradition of the Filipinos as the foundation of learning who the Filipinos really are is the aim of this research.

\section{OBJECTIVES}

The goal of this research is to put into record the oral literary traditions of modern Filipinos and to design a lesson manual to fit the new stipulations of the Commission on Higher Education in embracing the K-12 curriculum in the Philippine education system. Moreover, this research also analyzes the psyché of the people of Philippines through thematic categorization and mimetic analysis of the legends. The theme is the main concept or idea of the oral literary tradition. Themes describe the lives, human nature, and 
elements of the society. Identifying the themes allows the viewing of the people's beliefs and values. The mimetic theory believes that stories are created out of the unconscious feelings and sentiments of a group of people. People's attitudes, beliefs, feelings, values, and behaviors which form a certain culture in a region, are expressed by stories, such as legends that have been passed on from one person to another. These legends and stories may root from the society's unique mores, norms, and traditions.

This research assumes that the oral literary traditions of the Philippines, through their themes and archetypes, signify the collective Filipino psyché. This is supported by the theories of formalism and mimesis. In literary theory, formalism refers to critical approaches that analyze, interpret, or evaluate the inherent features of a text [3]. To view art basically in terms of the universe, in terms of what is imitated, is to follow the mimetic theory [4]. To determine the themes of the legends, formalism is employed; to analyze the archetypes to reveal the reality of human's unconscious, the theory of mimesis is at work.

Particularly, it delves into the following: 1). Cebuano Visayan orthographic standardization of the oral literary traditions' textuality; 2). their English translation; 3). their thematic analytical categorization; 4). their archetypal analysis; 5). the collective Filipino psyché reflected in the oral literary traditions; and 6). their historical, cultural, and spiritual implications. Finally, based on the findings, the lesson manual is created.

\section{LITERARY RESEARCH METHODOLOGY}

\section{A. Method Used}

This research utilizes the ethnoliterary research method in data-gathering, the local people of the Philippines as key informants, and the discourse analysis of literary texts using the formalistic and mimetic critical analyses for interpreting data. Ethnoliterary research is the study of the literatures of ethno (folk or people). In this research, interviewing the folks of the provinces of the Philippines is the method used to collect data.

\section{B. Sources of Verbal Data}

The sources of verbal data come from the ten key informants from the eight representative barangays of Philippines (Barangay is a political unit to refer to the Filipino town.) : Barangay Bakilid, Barangay Basak, Barangay Cabancalan, Barangay Maguikay, Barangay Pagsabungan, Barangay Tawason, Barangay Tipolo, and Barangay Subangdaku. From the ten key informants, ten oral literary traditions were collected. Table I shows the profile of the key informants of the literary ethnography. The profile includes the barangay and the oral literary tradition from that barangay.

\section{Data-Gathering Procedure}

Six phases are sequentially followed in the generation of verbal data toward completing this literary ethnographic research: Cebuano Visayan orthorgraphic textual standardization (phase one), English textual translation (phase two), thematic analytical categorization (phase three), archetypal analysis (phase four), collective Filipino psyché analysis (phase five) and historical, cultural, and spiritual implications (phase six).

TABLE I: THE KEY INFORMANTS OF THE LITERARY ETHNOGRAPHY

\begin{tabular}{|c|c|c|c|c|}
\hline Name & Age & Gender & Barangay & $\begin{array}{c}\text { Oral Literary } \\
\text { Traditions } \\
\end{array}$ \\
\hline $\begin{array}{c}\text { 1. Informant } \\
\text { A }\end{array}$ & $\begin{array}{c}22 \\
\text { years old }\end{array}$ & Male & 1. Bakilid & \begin{tabular}{|l}
$1 . \quad$ Ang \\
Nagpahinumdum \\
nga Agalun \\
(The Haunting \\
Master) \\
\end{tabular} \\
\hline $\begin{array}{l}\text { 2. Informant } \\
\text { B }\end{array}$ & $\begin{array}{c}61 \\
\text { years old }\end{array}$ & Female & 2. Basak & $\begin{array}{l}\text { 2. Ang Sigbin } \\
\text { (The Witch-pet) }\end{array}$ \\
\hline $\begin{array}{l}\text { 3. Informant } \\
\text { C }\end{array}$ & $\begin{array}{c}45 \\
\text { years old }\end{array}$ & Female & 3. Cabancalan & $\begin{array}{l}\text { 3. Ang Kugita } \\
\text { (The Octopus) }\end{array}$ \\
\hline $\begin{array}{l}\text { 4. Informant } \\
\text { D }\end{array}$ & $\begin{array}{c}18 \\
\text { years old }\end{array}$ & Female & 4. Maguikay & $\begin{array}{l}\text { 4. Ang Ungu } \\
\text { (The Witch) }\end{array}$ \\
\hline $\begin{array}{c}\text { 5. Informant } \\
\text { E }\end{array}$ & $\begin{array}{c}23 \\
\text { years old }\end{array}$ & Male & 5. Pagsabungan & $\begin{array}{l}\text { 5. Ang Wakwak } \\
\text { (The Witch-bird) }\end{array}$ \\
\hline $\begin{array}{c}\text { 6. Informant } \\
\text { F }\end{array}$ & $\begin{array}{c}51 \\
\text { years old }\end{array}$ & Female & \multirow{3}{*}{ 6. Tawason } & $\begin{array}{l}\text { 6. Di Ingun Natu } \\
\text { (The Supernatural } \\
\text { Beings) }\end{array}$ \\
\hline $\begin{array}{l}\text { 7. Informant } \\
\mathrm{G}\end{array}$ & $\begin{array}{c}42 \\
\text { years old }\end{array}$ & Female & & $\begin{array}{l}\text { 7. Ang Mga } \\
\text { Puti'ng Iring } \\
\text { (The White Cats) }\end{array}$ \\
\hline $\begin{array}{l}\text { 8. Informant } \\
\mathrm{H}\end{array}$ & $\begin{array}{c}36 \\
\text { years old }\end{array}$ & Female & & $\begin{array}{l}\text { 8. Ang Babayi sa } \\
\text { Iskuylahan } \\
\text { (The Woman in the } \\
\text { School) } \\
\end{array}$ \\
\hline 9. Informant I & $\begin{array}{c}18 \\
\text { years old }\end{array}$ & Female & 7. Tipolo & $\begin{array}{l}9 . \\
\text { Istudyanti'ng } \\
\text { Nasudlan ug } \\
\text { Ispiritu } \\
\text { (The } \\
\text { Spirit-possessed } \\
\text { Student) }\end{array}$ \\
\hline $\begin{array}{l}\text { 10. Informant } \\
\mathrm{J}\end{array}$ & $\begin{array}{c}61 \\
\text { years old }\end{array}$ & Female & 8. Subangdaku & $\begin{array}{l}\text { 10. Ang Wayt Lidi } \\
\text { (The White Lady) }\end{array}$ \\
\hline
\end{tabular}

(This shows the list of the profile of the key informants, including their age, gender, barangay, and the oral literary tradition told.)

Phase One: Cebuano Visayan Textual Standardization.

The ten oral literary traditions as encoded orally and decoded textually go through the scholarly linguistic process of orthographic standardization following Pesirla's Cebuano Visayan linguistic standard phoneme-grapheme correspondence.

Cebuano Visayan, the linguistic medium of the ten oral literary traditions of Philippines under investigation, is a phonetic language (spelled as sounded), hence it should be spelled using only the vowels $a, u, i$, the only Cebuano Visayan segmental speech sounds representing the vowels [5].

In like manner, all the fifteen consonant speech sounds of Cebuano Visayan should be spelled as sounded in all the words: $b, k, d, g, h, l, m, n, n g, p, r, s, t, w, y[6]$.

Thus, the textuality of the ten oral literary traditions in Cebuano Visayan should follow the appropriate spelling patterns of a phonetic language using its distinct scholarly authenticity.

Phase Two: English Textual Translation. Once the ten oral literary traditions go through the orthographic standardization of their Cebuano Visayan textualities, all of them are translated into English textualization.

Each oral literary tradition in Cebuano Visayan text is translated into English for the purpose of scholarly textual analysis in the English medium. Since languages are unique, 
thus the translation process goes through cross-lingual equivalence and idiom-to-idiom crossing rather word-for-word transliteration.

Analytical descriptions are accounted for under the translated text through process explanations.

Phase Three: Thematic Analytical Categorization. The oral literary traditions undergo thematic analyses, delineating the central message signified by each of the ten legends using oral textualities as mimesis of ethnicity in the local setting of Philippine barangays.

The ten oral literary traditions are then categorized and grouped based on related themes as analyzed.

The verbal data are analyzed using his descriptive table on themetic analytical categorization.

Phase Four: Archetypal Analysis. The ten oral literary traditions of the Philippines are then subjected to analyses of the archetypes that they contain as innate literary components of their fictional narrative constructs.

The ethnographic significance of these archetypes relate to the ethnicity of meaning that they express in the ten oral literary traditions, explaining superstitious beliefs, behavior patterns, values, and societal idiocyncracies distinctly of Filipinos.

Archetypes, thus, are analyzed as objects or images or signifiers of a societal message that distinctly exists in a local culture [7] in these barangays of the Philippines. Their signifieds, therefore, are the realities existing in society.

The verbal data on archetypes in the literary constructs of the ten oral literary traditions from the Philippines are summarized in this descriptive table for analysis.

Phase Five: Collective Filipino Psyché Analysis. The fifth phase in the ethnographic analyses of the oral literary traditions involves a synthesis of the themes and the archetypes with the end-in-view of producing an analytical collective psyche of the people of Philippines through the significance of the ten oral literary traditions. A collective unconscious, which refers to a storehouse of images and patterns, vestigial traces of which inhere all human beings and which find symbolic expression in all human art, is a reservoir of the experiences of Filipino species. This collective psyche is conceived of as a set of behaviour patterns and attitudes of superstition that characterize the Filipinos as revealed by the categories of themes and the significations of archetypes distinct to the ten oral tales.

Phase Six: Historical, Cultural, and Spiritual Implications. After analyzing the Filipino psyché reflected in the oral literary traditions, a discussion on the implications of the Filipino inner thoughts to their history, culture, and spirituality are discussed.

\section{The Output of the Study: Lesson Manual for K-12 Revised Curricula on Literature, History, and Social Studies}

Based on the findings with the anthology of the oral literary traditions in English and Cebuano-Visayan, the thematic analytical categorization, the archetypal analysis, the collective Filipino psyché reflected in the oral literary traditions, and their historical, cultural, and spiritual implications, the lesson manual is crafted to meet the requirements of the new subjects for the revised curriculum of both students in the Senior high school and in the higher education.

\section{FINDINGS}

The ten oral literary traditions in their Cebuano-Visayan orthographic standardization and English translations are in print. To summarize the content of every legend, Table II provides the main idea of each legend.

TABLE II: THEMATIC ANALYTICAL CATEGORIZATION

\begin{tabular}{|c|c|c|}
\hline $\begin{array}{c}\text { Oral Literary } \\
\text { Tradition } \\
\end{array}$ & Themes & $\begin{array}{c}\text { Analytical } \\
\text { Category }\end{array}$ \\
\hline $\begin{array}{l}\text { 1. Ang Sigbin } \\
\text { (The Witch-pet) }\end{array}$ & $\begin{array}{l}\text { The witch-pet whose } \\
\text { master is a witch, attacks } \\
\text { the field and helps its } \\
\text { master in killing } \\
\text { somebody. }\end{array}$ & \multirow{6}{*}{$\begin{array}{l}\text { The Existence } \\
\text { of Evil Forces } \\
\text { or Powers on } \\
\text { Earth }\end{array}$} \\
\hline $\begin{array}{l}\text { 2. Ang Ungu } \\
\text { (The Witch) }\end{array}$ & $\begin{array}{l}\text { The witch performs } \\
\text { rituals to gain power, } \\
\text { which helps her transform } \\
\text { into another form and kill } \\
\text { somebody. }\end{array}$ & \\
\hline $\begin{array}{l}\text { 3. Ang Di Ingun Natu } \\
\text { (The } \quad \text { Supernatural } \\
\text { Being) }\end{array}$ & $\begin{array}{l}\text { The supernatural being } \\
\text { can imitate someone's } \\
\text { appearance and invade a } \\
\text { person's home. }\end{array}$ & \\
\hline $\begin{array}{l}\text { 4. Ang Babayi sa } \\
\text { Iskuylahan } \\
\text { (The Woman in the } \\
\text { School) }\end{array}$ & $\begin{array}{l}\text { The woman in the school } \\
\text { scares teachers and } \\
\text { children because there is } \\
\text { no record of her } \\
\text { existence, and she } \\
\text { appears without notice. }\end{array}$ & \\
\hline $\begin{array}{l}\text { 5. Ang Istudyanti'ng } \\
\text { Nasudlanug Ispiritu } \\
\text { (The Spirit-possessed } \\
\text { Student) }\end{array}$ & $\begin{array}{l}\text { A spirit possesses a body } \\
\text { of a student that leaves } \\
\text { the student harmful to self } \\
\text { and to others. }\end{array}$ & \\
\hline $\begin{array}{l}\text { 6. Ang Wayt Lidi } \\
\text { (The White Lady) }\end{array}$ & $\begin{array}{l}\text { The white lady appears in } \\
\text { the dark and inflicts } \\
\text { illness to people who } \\
\text { disturb her. }\end{array}$ & \\
\hline $\begin{array}{l}7 . \quad \text { Ang } \\
\text { Nagpahinumdum } \\
\text { Nga Agalun } \\
\text { (The Haunting Maste) }\end{array}$ & $\begin{array}{l}\text { The dead master haunts } \\
\text { his ex-slave by moving } \\
\text { things in the house. }\end{array}$ & \multirow{2}{*}{$\begin{array}{l}\text { The } \\
\text { Inevitability of } \\
\text { Life After } \\
\text { Death }\end{array}$} \\
\hline $\begin{array}{l}\text { 8. Ang Mga Puti'ng } \\
\text { Iring } \\
\text { (The White Cats) }\end{array}$ & $\begin{array}{l}\text { The dead relatives } \\
\text { reincarnated into white } \\
\text { cats to guide the living } \\
\text { relative. }\end{array}$ & \\
\hline $\begin{array}{l}\text { 9. Ang Kugita } \\
\text { (The Octopus) }\end{array}$ & $\begin{array}{l}\text { The monstrous octopus } \\
\text { captures children who } \\
\text { swim in the river. }\end{array}$ & \multirow{2}{*}{$\begin{array}{l}\text { The Protection } \\
\text { of the Young } \\
\text { and the } \\
\text { Defenseless }\end{array}$} \\
\hline $\begin{array}{l}\text { 10. Ang Wakwak } \\
\text { (The Witch-bird) }\end{array}$ & $\begin{array}{l}\text { The witch-bird kills or } \\
\text { eats the unborn fetus } \\
\text { inside the womb of a } \\
\text { pregnant woman. }\end{array}$ & \\
\hline
\end{tabular}

(This presents the oral literary tradition, their theme, and their thematic categorization.)

The ten oral literary traditions' themes are categorized analytically according to their relatedness into three thematic analytical categories, which then are discussed critically.

Under the first theme category: The Existence of Evil Forces or Powers, the following stories are identified: Ang Sigbin (The Witch-pet), Ang Ungu (The Witch), Ang Di Ingun Natu (The Supernatural Being), Ang Babayi sa Iskuylahan (The Woman in the School), Ang Istudyanti'ng Nasudlan ug Ispiritu (The Spirit-possessed Student), and Ang Wayt Lidi (The White Lady). This group of oral literary traditions expresses the beliefs of negative forces in the world. 
Man has believed in opposing factors: one which is good, and the other, which is bad. The evil forces or powers are considered to be on the bad or negative side. The evil forces seek to destroy man, physically, emotionally, and spiritually. The struggle is between the man and the evil one.

Under the second theme category: The Inevitability of Life After Death, the following stories are identified: Ang Nagpahinumdum nga Agalun (The Haunting Master) and Ang Mga Puti'ng Iring (The White Cats). This group of oral literary traditions demonstrates the idea that dead people still have souls that continually manifest in various ways, to tell the living people that they still exist even after death. Men want to believe that the people whom they have loved should not stop thinking and loving them, even when they are already physically dead.

Under the third theme category: The Protection of the Young and Defenseless, the following stories are identified: Ang Kugita (The Octopus) and Ang Wakwak (The Witch-bird). This group of oral literary traditions exhibits the concept that the young, weak, and defenseless of the society are more prone to be overpowered and killed by the evil forces or powers. These young and defenseless are physically disadvantaged, like the fetuses or the children. The people that surround them have the aspiration to help them.

The varied archetypes in the ten oral literary traditions are identified and analytically discussed based on their local and cultural significance. Archetypes, thus, are signifiers of existing local and cultural realities of the Filipinos (the signifieds).

These are synthesized in Table III.

TABLE III: ARCHETYPES IN THE ORAL LITERARY TRADITIONS

\begin{tabular}{|c|c|c|}
\hline $\begin{array}{l}\text { Oral Literary } \\
\text { Traditions }\end{array}$ & \multicolumn{2}{|c|}{ Archetypes } \\
\hline & Signifiers & Signified \\
\hline $\begin{array}{l}\text { 1. Ang Sigbin } \\
\text { (he Witch-pe) }\end{array}$ & $\begin{array}{l}\text { Sigbin } \\
\text { (Witch-pet) }\end{array}$ & Evil force \\
\hline $\begin{array}{l}\text { 2. Ang Ungu } \\
\text { (The Witch) }\end{array}$ & $\begin{array}{l}\text { Ungu } \\
\text { (Witch) }\end{array}$ & Evil force \\
\hline $\begin{array}{l}\text { 3. Ang Di Ingun Natu } \\
\text { (The Supernatural } \\
\text { Being) }\end{array}$ & $\begin{array}{l}\text { Di IngunNatu } \\
\text { (Supernatural Being) }\end{array}$ & Evil Force \\
\hline $\begin{array}{l}\text { 4. Ang Babayi sa } \\
\text { Iskuylahan } \\
\text { (The Woman in the } \\
\text { School) }\end{array}$ & $\begin{array}{l}\text { Babayi sa Iskuylahan } \\
\text { (Woman in the School) }\end{array}$ & Evil Force \\
\hline $\begin{array}{l}\text { 5. Ang Istudyanti'ng } \\
\text { Nasudlan ug Ispiritu } \\
\text { (The Spirit-possessed } \\
\text { Student) }\end{array}$ & $\begin{array}{l}\text { Istudyanti'ng Nasudlan } \\
\text { Ug Ispiritu } \\
\text { (Spirit-possessed } \\
\text { Student) }\end{array}$ & Evil Power \\
\hline $\begin{array}{l}\text { 6. Ang Wayt Lidi } \\
\text { (The White Lady) }\end{array}$ & $\begin{array}{l}\text { Wayt Lidi } \\
\text { (White Lady) }\end{array}$ & Evil Force \\
\hline $\begin{array}{l}7 . \quad \text { Ang } \\
\text { Nagpahinumdum } \\
\text { Nga Agalun } \\
\text { (The Haunting } \\
\text { Master) } \\
\end{array}$ & $\begin{array}{l}\text { Nagpahinumdum } \\
\text { Nga Agalun } \\
\text { (Haunting Master) }\end{array}$ & $\begin{array}{l}\text { The dead } \\
\text { person's presence } \\
\text { among the living }\end{array}$ \\
\hline $\begin{array}{l}\text { 8. Ang Mga Puti'ng } \\
\text { Iring } \\
\text { (The White Cats) }\end{array}$ & $\begin{array}{l}\text { Mga Puti'ng Iring } \\
\text { (White Cats) }\end{array}$ & $\begin{array}{l}\text { The dead } \\
\text { people's presence } \\
\text { among the living }\end{array}$ \\
\hline $\begin{array}{l}\text { 9. Ang Kugita } \\
\text { (The Octopus) }\end{array}$ & Kugita (Octopus) & $\begin{array}{l}\text { Killer of young } \\
\text { children }\end{array}$ \\
\hline $\begin{array}{l}\text { 10. Ang Wakwak } \\
\text { (The Witch-bird) }\end{array}$ & $\begin{array}{l}\text { Wakwak } \\
\text { (The Witch-bird) }\end{array}$ & $\begin{array}{l}\text { Killer of unborn } \\
\text { children }\end{array}$ \\
\hline
\end{tabular}

(The table shows the oral literary traditions' archetypes, their signifiers and their signifieds)
Sigbin (Witch-pet) is a mythical creature in Cebu, Philippines that is kangaroo-like and can move fast and destroys plants and fields. Whether the report of the spotting of the said creature is true or not, its effect on the listeners is still the same: to incite fear. The supernatural powers that the sigbin (witch-pet) has, as well as its agalun (master), would make any people fearful of them. No people would go to the place where sigbins have been in.

Ungù (Witch) as a legendary character of the Philippines is a person who transforms themselves to a persona or a creature that has a supernatural ability to incite fear or inflict harm on others. The transformation begins after a ritual that consists of putting oil all over the body and chanting rites. Some people say that an ungù will transform into a beautiful woman to attract men to themselves. After they get their prey, they would either suck their blood (like vampires do), eat their organs, or cook them. Others would say that an ungù will transform into a wakwak (witch-bird) which enables them to have large, sharp (like knives) wings [8].

Dî ingun natù (Supernatural Being) is coined as such to mean as someone who is not like a mere human being. This is due to the fact that these supernatural beings cannot be seen, but their doings provide phenomena that are evident yet cannot be explained by human reason. There have been many kinds of supernatural beings retold by Filipinos. However, the most common origin regarding where these supernatural beings come from is that they live in trees. This belief is closely connected with the practices of pre-hispanic Filipinos who believed in supernatural beings living in the nature. During the Pre-Hispanic era, the Filipinos had a religious belief in nature worship [9].

Ang Babayi sa iskuylahan (The Woman in the School)'s usual description of the people who have alleged to have seen her is that she wears a long dress that is particularly colored white. This woman is mysterious in a way that she does not appear upfront to the people in the school. One instance is that a student, during their flag ceremony, has seen the woman hiding behind a post on the top floor. The woman in the school has appeared several times in passing to the people in the school. This woman appears, then disappears. There will be no trace of this woman's whereabouts. It is believed she shows up in the school since the school is surrounded by many trees. These trees are believed to be the abode of this woman in the school.

Ang Istudyanti'ng Nasudlan ug Ispiritu (The Spirit-possessed Student) is reported to have a "weak spirit" because of her not being religious and not being good. It is inculcated in the psyché of the people of Philippines that it is dangerous when one neglects their religious duty.

Ang Wayt Lidi (The White Lady) is one of the most popular figures of legendary Filipino oral traditions. This white lady appears to be a supernatural being with a feminine feature and one who has a long, white dress. Oftentimes, this lady is described to have long, black hair. People say that a white lady's face is blank or blurry. At other times, the white lady is described to be "gwapa" or beautiful.

Ang Nagpahinumdum nga Agalun (The Haunting Master) is a master who has died of heart attack and has an apparition or has caused an occurrence of unexplained 
phenomena, such as the moving of a pail and a phone. There are movements and sounds yet without the physical apparition at times when this haunting takes place. This invokes fear to his household help who has retold this story.

Ang Mga Puti'ng Iring” (The White Cats) are the "reincarnated" dead relatives of the informant who have died in a sunken ship and whose bodies are missing. The three relatives who have died are a group of family of a husband, a wife, and a child. This unusual occurrence of the three white cats in her house implies a supernatural phenomenon which is believed to be the transformation of the three dead members of the family into these three white cats.

Ang Kugita (The Octopus) is a monstrous octopus that captures children in the river where it resides. The "kugita" is to be blamed for the disappearance of the three children in the area. As a result, the children's father, out of anger for his children's death, bombs the river in the hope of killing the "kugita". The parents of the children are very protective of them that, whether the existence of kugita is true or not, the parents definitely disallow their children from going to the river. The account for the existence of the unusual, bigger than normal size of an animal is popular in the Philippines. The enlargement is at least one hundred times more than the normal size. Other instances told by Filipinos are the appearances of supersized pig, dog, crab, lobster, beetle, and cockroach.

Ang Wakwak (The Witch-bird) is vampiric-bird which is a transformation of a woman witch whose body separates from the trunk toward the head, while the rest of her body, the legs remain on the ground. It targets a pregnant woman for their prey. Informant E states that the wakwak does not normally eye on an ordinary person; rather, the wakwak has special liking for the fetus inside the womb of a pregnant woman. The husband is vigilant for any sound of a wakwak, especially noises from the roof. It is believed that the wakwak tags black cats with her to distract the husband, so that the wakwak can carry on her plan of cutting the abdomen of the pregnant woman through its wings, and finally taking out the unborn child. The unborn child serves as the wakwak's food.

The varied archetypes in the ten oral literary traditions are identified and analytically discussed based on their local and cultural significance.

The signifiers of the oral literary traditions with the signified, "evil force or power", are the following: Sigbin (Witch-pet), Ungù (Witch), Dî Ingun Natù (Supernatural Being), Babayi sa Iskuylahan (Woman in the School), Istudyanti'ng Nasudlan ug Ispiritu (Spirit-Possessed Student), and Wayt Lidi (White Lady).

The signifiers of the oral literary traditions with the signified, the dead person's presence among the living, are the following: Nagpahinumdum nga Agalun (Haunting Master) and Mga Puti'ng Iring (White Cats).

The signifiers of the oral literary traditions with the signified, killer of young or unborn children, are the following: Kugita (Octopus) and Wakwak (Witch-bird).

The signifiers of the oral literary traditions with the signified, "evil force or power", are the following: Sigbin (Witch-pet), Ungù (Witch), Dî Ingun Natù (Supernatural Being), Babayi sa Iskuylahan (Woman in the School), Istudyanti'ng Nasudlan ug Ispiritu (Spirit-Possessed Student), and Wayt Lidi (White Lady).

The signifiers of the oral literary traditions with the signified, the dead person's presence among the living, are the following: Nagpahinumdum nga Agalun (Haunting Master) and Mga Puti'ng Iring (White Cats).

The signifiers of the oral literary traditions with the signified, killer of young or unborn children, are the following: Kugita (Octopus) and Wakwak (Witch-bird).

Finally, a collective Filipino psyche is determined. Table IV summarizes the Filipino collective psyché which is signified by the oral literary traditions' themes and archetypes.

TABLE IV: The FILIPINOS' Collective PSYCHÉ

\begin{tabular}{|c|c|c|}
\hline $\begin{array}{l}\text { Categories of } \\
\text { Themes }\end{array}$ & $\begin{array}{c}\text { Significations of } \\
\text { Archetypes }\end{array}$ & $\begin{array}{l}\text { Behavior Patterns } \\
\text { and Attitudes }\end{array}$ \\
\hline $\begin{array}{l}\text { The Existence } \\
\text { of Evil Forces or } \\
\text { Powers on Earth }\end{array}$ & $\begin{array}{l}\text { The mythical creatures: } \\
\text { sigbin (witch-pet), ungù } \\
\text { (witch), di ingun natu } \\
\text { (supernatural being), } \\
\text { babayi sa iskuylahan } \\
\text { (woman in the school), } \\
\text { and wayt lidi (white lady } \\
\text { reveal evil forces here on } \\
\text { earth. The oral literary } \\
\text { tradition of "Ang } \\
\text { Istudyanti'ng Nasudlan } \\
\text { ug Ispiritu” (The } \\
\text { spirit-possessed student) } \\
\text { signifies the evil power } \\
\text { that may control a person. }\end{array}$ & $\begin{array}{l}>t u \text { - } u \text { - } t u-u \\
\text { (superstitious) } \\
>\text { ritualistic in } \\
\text { counteracting } \\
\text { threatening or } \\
\text { dangerous forces } \\
>\text { mahadlukun } \\
\text { (fearful) } \\
>\text { suspicious } \\
>\text { vigilant toward } \\
\text { threatening forces } \\
>\text { cautious } \\
>\text { religious } \\
>\text { sin conscious } \\
>\text { judgmental } \\
>\text { inclined to hearsays }\end{array}$ \\
\hline $\begin{array}{l}\text { The Inevitability } \\
\text { of Life after } \\
\text { Death }\end{array}$ & $\begin{array}{l}\text { "Ang Nagpahinumdum } \\
\text { nga Agalun" (The } \\
\text { Haunting Master) and the } \\
\text { "Ang Mga Puti'ng Iring” } \\
\text { (The White Cats) signify } \\
\text { the dead person's presence } \\
\text { among the living. }\end{array}$ & $\begin{array}{l}\text { > split-level } \\
\text { Christianity } \\
>\text { believer in life after } \\
\text { death } \\
>\text { respectful toward } \\
\text { the dead } \\
>\text { believer in the dead } \\
\text { protecting the living } \\
>\text { devoted to relatives }\end{array}$ \\
\hline $\begin{array}{l}\text { The Protection } \\
\text { of the Young } \\
\text { and Defenseless }\end{array}$ & $\begin{array}{l}\text { Kugita (Octopus) and } \\
\text { wakwak (witch-bird) are } \\
\text { mythical creatures that are } \\
\text { killers of young and } \\
\text { unborn children. }\end{array}$ & $\begin{array}{l}>\text { protective of the } \\
\text { unborn and young } \\
\text { children } \\
>\text { devoted to family } \\
>\text { brave in overcoming } \\
\text { evil forces }\end{array}$ \\
\hline
\end{tabular}

The collective psyché of the people of the Philippines reveals the traits of being superstitious, religious, sin conscious, vigilant, cautious, suspicious, judgmental, mahadlukun" or fearful, inclined to hearsays, believer in the dead protecting the living, and devoted their family.

Based on the analytical synthesis of the ten oral literary traditions' thematic categories and archetypal significations, a collective pattern of behavior and attitudes is significantly constructed, critically describing the people of Philippines as superstitious. These behaviors have their historical root dated in the pre-hispanic period when paganism, animism, and Hindu practices, traditions, and beliefs dominated Filipino culture. Christianity, introduced during the Spanish period, has become a pinnacle of spiritual faith among most modern Filipinos since the time of its conception in the Philippines. Christian doctrines do not support most of the collective behavior and attitudes of Filipinos of today which have been carried on from the early Filipinos until the present through the oral lore. Some of these traits which oppose the Christian 
teaching are being superstitious, ritualistic, fearful, sin conscious, and judgmental. The belief of life after death and the visiting of dead people on the earth are also contradictory to the Christian faith.

\section{CONCLUSION}

This study on the oral literary traditions of the Philippines can be used to propose a manual that corresponds to the standards of the new subject offerings on literature, history and social studies brought about by the newly implemented K-12 Enhanced Basic Education Act of 2013.

\section{ACKNOWLEDGMENT}

The author wishes to extend her gratitude to the following literature academics who have reviewed and made suggestions on this research: Dr. Angel O. Pesirla, Dr. Edwin A. Pilapil, Dr. Reynaldo A. Caturza, Dr. Glen M. Pesole, and Dr. Leonora T. Dotillos. In addition, she is grateful to International Conference on Languages, Literature and Linguistics-ICLLL 2014 for the reviews and comments that have polished this research work.

\section{REFERENCES}

[1] B. Lumbera and C. Lumbera, Philippine Literature: A History and Anthology, Pasig City, Philippines: Anvil Publishing, 2005, p. 2.

[2] T. Agoncillo, History and Culture, Language, and Literature: Selected Essays, Manila, Philippines: University of Sto. Tomas Publishing House, 2003, pp. 81-82.

[3] Wikipedia: The Free Encyclopedia. (2014). Formalism (literature) [Online].

Available:
[4] W. Hamon, A Handbook to Literature, New Jersey: Prentice Hall Inc., 1996, p. 124.

[5] A. O. Pesirla, Ang Mga Sistima'ng Linggwistika sa Sugbu-anun'g Bisaya (The Linguistic System of Cebuano-Visayan), Cebu City, Philippines: Carangue Printing Corp., 2003, pp. 1-2.

[6] R. Barthes. (1968). Elements of Semiology. Philosopohy Archive. [Online]. Available: http://www.marxists.org/reference/subject/philosophy/works/fr/barthe s.htm

[7] C. G. Jung, Archetypes and the Collective Unconscious, Princeton University Press, Aug. 1, 1981, p. 6.

[8] Wikipedia: The Free Encyclopedia. (2011). Wakwak. [Online] Available: http://en.wikipedia.org/ wiki/Wakwak

[9] T. D. C. Tuazon and B. S. Medina Jr., Philippine Literature: From Ancient Times to the Present, Quezon City: Philippines Free Press, 1964, p. 5 .

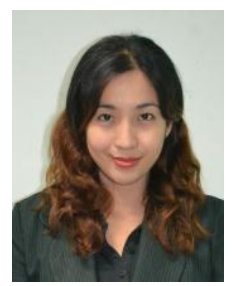

Doris Ogdoc-Gascon was born in Cebu, Philippines on November 13, 1986. She has finished her master's degree in literature in 2012, and is currently finishing her dissertation for her doctorate degree in literature and communication at Cebu Normal University. Moreover, she is a licensed teacher and nurse.

She had worked as an editor in a market research firm (Opinionology, Inc.) for three years from 2008 to 2011. Currently, she is a university instructor at a state college in the Philippines: Cebu Technological University. She is handling subjects for postgraduate studies (MA.Ed in English teaching) and undergraduate program of the bachelor of arts in English major in applied linguistics. She is also the chairperson for Publication of the Journal on Arts and Sciences of the university.

An avid fan of literature and a literary artist herself, Ms. Doris O. Gascon, has won first prizes in short story and creative writing contests. Her on-going dissertation is D.O. Gascon's Yeshua in Yolanda, which is a creative work in novelette narrating the stories of the survivors of the Super Typhoon Haiyan of 2013, also locally called Yolanda, and how spirituality is at work when the calamity struck. She is interested in contributing local literature and regional culture to the modern-day Filipinos. 